Nigerian Journal of Physiological Sciences 22 (1-2): 99-104 @Physiological Society of Nigeria, 2007

Available online/abstracted at http://www.biolineinternational.org.br/njps; www.ajol.info/journals.njps; www.cas.org

\title{
EFFECT OF ALCOHOL AND KOLANUT INTERACTION ON BRAIN SODIUM PUMP ACTIVITY IN WISTAR ALBINO RATS.
}

\author{
G. O. OBOCHI ${ }^{1}$, A. E. ABARA, S. P. MALU ${ }^{1}$, M. OBI-ABANG ${ }^{1}$, F. E. \\ EDU $^{1}$ M. U. ETENG ${ }^{2}$, AND I. B. UMOH ${ }^{2}$. \\ ${ }^{I}$ Department of Biochemistry, Cross River University Of Technology, Calabar. \\ ${ }^{2}$ Department of Biochemistry, University of Calabar.
}

Summary: Effect of alcohol - kolanut interaction on Sodium Pump activity in wistar albino rats was studied. Thirty wistar albino rats were divided into six groups of five (5) rats per group and used for the study. The control group (1) received via oral route a placebo $(4 \mathrm{ml}$ of distilled water). Groups 2 to 6 were treated for a period of 21 days, with $(10 \% \mathrm{v} / \mathrm{v}$ ) of alcohol (group 2), 50mg/kg body weight of kolanut (group 3), 50mg/kg body weight of caffeine (group 4), $4 \mathrm{ml}$ of $10 \% \mathrm{v} / \mathrm{v}$ of alcohol and $50 \mathrm{mg} / \mathrm{kg}$ body weight kolanut (group 5), $4 \mathrm{ml}$ of $10 \% \mathrm{v} / \mathrm{v}$ of alcohol and $50 \mathrm{mg} / \mathrm{kg}$ body weight of caffeine in $4.0 \mathrm{ml}$ of the vehicle via gastric intubation respectively. A day after the final exposure, the brain of each rat was harvested and processed to examine several biochemical parameters, i.e., total ATpase, ouabain-insensitive ATpase, ouabain sensitive ATpase $\left(\mathrm{Na}^{+}-\mathrm{K}^{+}\right.$- ATpase), non-enzymatic breakdown of ATP and inorganic phosphate $\left(\mathrm{P}_{\mathrm{i}}\right)$ released. The results showed that the essential enzyme of the brain responsible for neuronal function, $\mathrm{Na}^{+}-\mathrm{K}^{+}-$ATpase, was inhibited by alcohol-kolanut coadministration relative to control, resulting in a decrease in $\mathrm{Na}^{+}-\mathrm{K}^{+}$- ATpase activity, ATP production, ion transport and action potential, leading to loss of neuronal activities.

Key Words: Alcohol, Kolanut, Caffeine Interaction, $\mathrm{Na}^{+}-k^{+}-$ATPase, activity

\section{Introduction}

Brain function involves subtle chemical and electrical processes, which can easily be altered and modified with the use of various psychoactive drugs (Obochi, 2006). The major function of the neuronal tissue is the generation and transmission of impulses which take the form of electrical discharges along the nerve fibre. This is measured by the activity of $\mathrm{Na}^{+}-$ $\mathrm{K}^{+}$-ATPase, which is a transmembrane protein and a key enzyme that maintains membrane ionic gradient with respect to $\mathrm{Na}^{+}$and $\mathrm{K}^{+}$ exchange across the membrane. $\mathrm{Na}^{+}-\mathrm{K}^{+}$-ATPase actively transports $\mathrm{Na}^{+}$into the extracellular fluid. It is a glycoprotein composed of $2 \alpha$ and $2 \beta$ chains, and its activity depends on presence of $\mathrm{Na}^{+}$and $\mathrm{K}^{+}$and requires ATP and $\mathrm{mg}^{2+}$ ions as cofactors. The enzyme hydrolyzes a high energy phosphate bond of ATP and uses the energy thus release to transport $3 \mathrm{Na}^{+}$ions outside and simultaneously $2 \mathrm{~K}^{+}$ions inside across the cell membrane (Obochi, 2006). The levels of $\mathrm{Na}^{+}-\mathrm{K}^{+}$-ATPase, therefore reflects the activity of the neuron, hence, neuronal function.

Many constituents of the diet have impact on neuronal function through their effect on this enzyme, either by stimulating or depressing its activity. Notable amongst these dietary constituent are alcohol and kolanuts. Both alcohol and kolanut are common items of entertainment consumed concurrently in community functions. Kolanut contains constituents, kolanin, quinine, caffeine, theobromine and theophylline (Adeyeye and Ayejuyo, 1994; Eteng et al, 1997; Abulude, 2004). These constituents are also found as constituents of coffee, cocoa, bean seeds as well as tea leaves and are widely consumed through their beverages such as snacks (coke, schwebbs, bitter lemon) pharmaceutical products, over the counter drugs, and extracts of coffee, cocoa and kolanuts (Adeyeye and Adejuyo, 1994; Eteng et al, 1997; Abulude, 2004; Obochi, 2006). These beverages were valued as foods, medicine and ceremonial drinks. Alcohol is widely consumed through alcoholic beverages such as table wines, beers, desert or cocktail wines, cordials, liquors, whisky and brandy. Although, negligibly nourished, alcohol is an energy producing food like sugar (El-mas et al, 1994; Dorhman et al, 1997; Fadda and Rossetti, 1998; Koobs et al, 1998; Lieber, 1999; 2000; Obochi, 2006). These drugs (alcohol and kolanuts) have opposing effects on the brain and their 
metabolic interaction since there are consume concurrently may be of importance for diagnosis and or treatment of neuronal disorders (Obochi, 2006). A survey of available literature fails to show any report assessing the effect of alcohol-kolanut interaction on neuronal activity as measured by the principal or key enzyme of sodium pump action. The present study therefore evaluate the effect of alcohol kolanut interaction on brain sodium pump activity in albino wister rats.

\section{Material and Methods \\ Experimental Animals:}

Thirty (30) Wistar albino rats weighing between $150-280 \mathrm{~g}$ obtained from the disease free stock of the animal house, Department of Biochemistry, College of Medical Sciences, University of Calabar, Nigeria were used for the study. The animals were randomly assigned into six (6) groups of five (5) animals per group. Each rat in a study group was individually housed in a stainless cage with plastic bottom grid and a wire screen top. The animal room was adequately ventilated, and kept at room temperature and relative humidity of $29 \pm 2^{0} \mathrm{c}$ and $40-70 \%$ respectively with 12 hour natural light-dark cycle.

\section{Treatment Regimen}

The animals were fed ad libitum with water and rat chow (livestock feeds Ltd, Calabar, Nigeria). Good hygiene was maintained by constant cleaning and removal of faeces and spilled feed from cages daily. The control group (1) received via oral route (oral gavage) a placebo ( $4 \mathrm{ml}$ of distilled water). Groups 2 to 6 were treated for a period of 21 days with $(10 \% \mathrm{v} / \mathrm{v}) 50 \mathrm{mg} / \mathrm{kg}$ body weight of alcohol, $50 \mathrm{mg} / \mathrm{kg}$ body weight of kolanut, $50 \mathrm{mg} / \mathrm{kg}$ body weight of caffeine, $50 \mathrm{mg} / \mathrm{kg}$ body weight of alcohol and $50 \mathrm{mg} / \mathrm{kg}$ body weight of kolanut, and $50 \mathrm{mg} / \mathrm{kg}$ body weight of alcohol and $50 \mathrm{mg} / \mathrm{kg}$ body weight of caffeine in $4.0 \mathrm{ml}$ of the vehicle via gastric intubation, respectively. The experiments were conducted between the hours of 9.00am and 10.00am daily.

\section{Sample Preparation}

One day after the final exposure, the animals were suffocated by inhalation of an over dose of chloroform. The brain of each rat was harvested, ground using mortar and pistle, and buffered with TRIS-HCL buffer, $\mathrm{pH}$ 7.4. A whole homogenate (WH) was prepared by centrifugation (4000xg, 30 minutes). The supernatant was again centrifuged $(6000 \mathrm{xg}, 20$ minutes) and made up to $100 \mathrm{ml}$ mark with the TRIS-HCL buffer, $\mathrm{pH} 7.4$ in a volumetric flask.
The whole homogenate thus obtained was stored at $-7^{\circ} \mathrm{C}$ in the freezer and used for the various assays.

\section{Preparation of Caffeine}

Synthetic caffeine was obtained from May and Baker (M\&B) limited, Enfield, Middle Sex, United Kingdom, and used for the study. A stock solution of caffeine was prepared by dissolving $20 \mathrm{~g}$ of powder caffeine in $500 \mathrm{ml}$ of hot distilled water. The solution was allowed to cool to room temperature, and $50 \mathrm{mg} / \mathrm{kg}$ body weight of caffeine was administered to groups 4 and 6 in $4.0 \mathrm{ml}$ of the vehicle via gastric intubation.

\section{Preparation of Kolanut}

Kolanuts were obtained from the Bogobiri market, Calabar, Nigeria and used for the study. The kolanuts were washed, an dried at $60^{\circ} \mathrm{c}$ for 12 hours, and ground using electric kenwood blender. $20 \mathrm{~g}$ of the kolanut was dissolved in $500 \mathrm{ml}$ of hot distilled water. Out of the stock solution prepared $50 \mathrm{mg} / \mathrm{kg}$ body weight was administered to the animals in groups 3 and 5 in $4.0 \mathrm{ml}$ of the vehicle via gastric intubation.

\section{Preparation of Alcohol}

The alcohol used was distilled from palm wine (Elias guinensis) using quick fit distillation apparatus. $10 \% \mathrm{v} / \mathrm{v}$ of the alcohol was prepared by adding to $10 \mathrm{ml}$ of alcohol, $80 \mathrm{ml}$ of distil water to make up $100 \mathrm{ml}$. And $4 \mathrm{ml}$ of this stock, was administered to the animals in groups 2, 5 and 6 in gastric intubation.

\section{Biochemical Assays}

The whole homogenate (WH) obtained was used for the analysis of brain total ATpase, ouabain-insensitive ATpase, ouabain-sensitive ATpase $\left(\mathrm{Na}^{+}-\mathrm{K}^{+}\right.$-ATpase $)$, non-enzymatic breakdown of ATP and inorganic phosphate $\left(\mathrm{P}_{\mathrm{i}}\right)$ released.

Adenosine 5-Triphosphatase (total ATPase) and Ouabain-sensitive ATPase $\left(\mathrm{Na}^{+}-\right.$ $\mathrm{K}^{+}$-ATPase) in rat brain were determined with modifications of the methods of Sigstrom et al (1981), which represent the methods of Sigstrom and Walderstrom (1980). Dilute homogenates were prepared $(2 \% \mathrm{~W} / \mathrm{V})$ in icecold 250mmol sucrose, 5mmol EDTA, 20mmol imidazole ( $\mathrm{pH}$ 7.4) using a glass-glass homogenizer. A mild detergent treatment was applied to the samples prior to the assay to elicit maximal $\mathrm{Na}^{+}-\mathrm{K}^{+}$-ATPase activity. A $1.50 \mathrm{mg}$ volume of homogenate was mixed under constant stirring with $1.50 \mathrm{mg}$ of sodium deoxycholate $(1 \mathrm{mg} / \mathrm{ml})$ and was allowed to stand at room temperature for 15 minutes. $0.50 \mathrm{mg}$ of the detergent treated homogenates 
were then preincubated in $\mathrm{Na}^{+}-\mathrm{K}^{+}$-ATPase assay medium (in mmol 30 histidine, $4 \mathrm{MgCl}_{2}$, $124 \mathrm{NaCl}$, or $20 \mathrm{KCl}(\mathrm{pH} 7.5$ ) for 10 minutes at $37^{\circ} \mathrm{C}$ (mammals) or $40^{\circ} \mathrm{C}$ (birds) to allow for thermal equilibration and binding of Ouabain to the sodium pumps. Enzyme activity was initiated by the addition of $3 \mathrm{mmol}$ ATP and allowed to proceed for 5 minutes. The reaction was terminated by the addition of an equal volume of perchloric acid $(0.8 \mathrm{mmol})$ at $37^{\circ} \mathrm{c}$.

Inorganic phosphate $(\mathrm{Pi})$ released was determined by a modified method of Taussky Shorr as described by Fiske and Subbarrow (1925). Briefly, $1.0 \mathrm{ml}$ of the homogenate was measured and $1.0 \mathrm{ml}$ of $0.5 \mathrm{~N}$ TCA was added and mixed vigorously. Then $1.0 \mathrm{ml}$ of molybdate reagent (i.e., $4 \mathrm{ml}$ of $16 \%$ ammonium molybdate in $10 \mathrm{~N} \mathrm{H}_{2} \mathrm{SO}_{4}, 36 \mathrm{ml}$ of $\mathrm{H}_{2} \mathrm{O}$, and $2 \mathrm{~g}$ of $\mathrm{FeSO}_{4} \cdot 7 \mathrm{H}_{2} \mathrm{O}$ ) was added and mixed again. This was prepared just prior to use. The solution was then incubated for 5 minutes at room temperature and the absorbances read at $660 \mathrm{~nm}$ against a water blank in a spectrophotometer. Maximal $\mathrm{Na}^{+}-\mathrm{K}^{+}$-ATPase activity was calculated as the difference in inorganic phosphate (Pi) liberated (from ATP) in the presence and absence of $1 \mathrm{mmol}$ Ouabain (minus and plus $\mathrm{KCl}$ respectively). Experiments were conducted in triplicate to minimize variation and improve accuracy and precision of results. The activity of the enzyme was expressed in nanomoles of inorganic phosphate $(\mathrm{Pi})$ ion released per milligram of protein per hour (i.e. nmoles. Pimg ${ }^{-1}$ proteinhr ${ }^{-1}$ ).
Statistical Analysis

Data collected were expressed as mean \pm standard deviation (SD), analysis of variance (ANOVA) and the student ' $\mathrm{t}$ ' test were used for analysis. Values of $\mathrm{p}<0.05$ were regarded as significant.

\section{Results}

Total ATpase represents the inorganic phosphate $\left(\mathrm{P}_{\mathrm{i}}\right)$ liberated in the absence of ouabine while ouabain-insensitive represents the inorganic phosphate $\left(\mathrm{P}_{\mathrm{i}}\right)$ released in the presence of ouabain. The $\mathrm{Na}^{+}-\mathrm{K}^{+}$-ATPase activity represents the difference in inorganic phosphate $\left(\mathrm{P}_{\mathrm{i}}\right)$ liberated from ATP in the absence and presence of ouabain, which is a cardiac glycoside and a key inhibitor of the $\mathrm{Na}^{+}-$ $\mathrm{K}^{+}$-ATPase.

Tables 1 and 2 present the results of the effect of the treatment interaction on brain total ATpase, ouabain-insensitive, ouabain-sensitive ATpase, $\quad \mathrm{Na}^{+}-\mathrm{K}^{+}$-ATPase, non-enzymatic breakdown of ATP and inorganic phosphate (Pi) released respectively. The results showed that kolanut and caffeine independently produced an increase in $\mathrm{Na}^{+}-\mathrm{K}^{+}$-ATPase activity compared with the controls, while there was a significant $(\mathrm{P}<0.05)$ decrease in the $\mathrm{Na}^{+}-\mathrm{K}^{+}$-ATPase values of the alcohol, alcohol-kolanut and alcohol caffeine treated groups when compared with the controls. Alcohol-kolanut treatment resulted in an interaction that significantly $(\mathrm{P}<0.05)$ decreased the activity of $\mathrm{Na}^{+}-\mathrm{K}^{+}$-ATPase. The same pattern of effect was observed in the alcohol-caffeine treated group. This results shows that alcohol suppressed the effects of kolanut and caffeine respectively.

Table 1: Effects of the treatment on brain $\mathrm{Na}^{+}-\mathrm{K}^{+}$-ATPase activity in Wistar albino rats

\begin{tabular}{llll}
\hline Group(N) & $\begin{array}{l}\text { Brain total } \\
\text { ATPase ATPase } \\
(\mathrm{nmolesPimg} \\
\text { proteinhr }\end{array}$ & $\begin{array}{l}\left.\text { Ouabain }^{-1}\right) \\
\left(\mathrm{Na}^{+}-\mathrm{K}^{+}-\mathrm{ATPase}\right) \\
\left(\mathrm{nmolesPimg}^{-}\right) \\
\left.\text {proteinhr }^{-1}\right)\end{array}$ & $\begin{array}{l}\text { Ouabain } \\
\text { Sensitive } \\
\left(\mathrm{Na}^{+}-\mathrm{K}^{+}-\mathrm{ATPase}\right) \\
\left(\mathrm{nmolesPimg}^{-}\right. \\
\left.\text {proteinhr }^{-1}\right)\end{array}$ \\
\hline 1. Control & $20.34 \pm 1.89$ & $12.22 \pm 1.31$ & $8.12 \pm 0.58$ \\
2. Alcohol & $13.65 \pm 1.79^{*}$ & $8.84 \pm 1.48^{*}$ & $5.17 \pm 0.31^{*}$ \\
3. Kolanut & $28.67 \pm 2.77^{*}$ & $17.59 \pm 1.67^{*}$ & $11.08 \pm 0.39^{*}$ \\
4. Caffeine & $33.27 \pm 2.77^{*}$ & $20.68 \pm 1.98^{*}$ & $12.59 \pm 0.79^{*}$ \\
5. Alcohol-kolanut & $14.76 \pm 1.56^{*}$ & $8.87 \pm 1.43^{*}$ & $5.89 \pm 0.13^{*}$ \\
6.Alcohol-caffeine & $9.51 \pm 1.26^{*}$ & $5.38 \pm 1.37^{*}$ & $4.16 \pm 0.11^{*}$ \\
\hline
\end{tabular}

$N=$ Number of rats per group $=5$. Values are expressed as mean $\pm S D$.

$*$ = Significantly different from control, $P<0.05$, using student 't'test.

Values of $\mathrm{Na}^{+}-\mathrm{K}^{+}$-ATPase are expressed as difference between total ATPase and Ouabain-insensitive ATPase. 
Table 2: Effects of the treatment on non-enzymatic breakdown of ATP and inorganic phosphate (Pi) released in Wistar albino rats.

\begin{tabular}{|c|c|c|}
\hline Group(N) & $\begin{array}{l}\text { Non Enzymatic } \\
\text { breakdown of } \\
\text { ATP } \\
(\text { nmolesPimg } \\
\left.{ }^{1} \text { proteinhr }^{-1}\right)\end{array}$ & $\begin{array}{l}\text { Inorganic } \\
\text { Phosphate }(\mathrm{Pi}) \\
\text { released } \\
\left(\text { nmolesPimg }^{-}\right. \\
\left.{ }^{1} \text { proteinhr }^{-1}\right)\end{array}$ \\
\hline 1. Control & $7.81 \pm 1.34$ & $7.48 \pm 1.44$ \\
\hline 2. Alcohol & $5.25 \pm 1.21 *$ & $4.31+0.67 *$ \\
\hline 3. Kolanut & $9.87 \pm 1.69 *$ & $9.53 \pm 1.68 *$ \\
\hline 4. Caffeine & $11.5 \overline{8} \pm 1.69$ & $13.1 \overline{6}+1.87^{*}$ \\
\hline 5. Alcohol-kolanut & $4.37 \pm 1.24 *$ & $4.12 \pm 0.58 *$ \\
\hline 6.Alcohol-caffeine & $5.75+1.23 *$ & $5.28+0.79 *$ \\
\hline
\end{tabular}

$N=$ Number of rats per group $=5$. Values are expressed as mean $\pm S D$

*Significantly different from control, $P<0.05$, using ANOVA and student ' $t$ ' test.

\section{Discussion}

The effect of alcohol-kolanut interaction on brain sodium pump activity in albino wister rats was evaluated in this study. Kolanut and caffeine were independently found to increase the activity of $\mathrm{Na}^{+}-\mathrm{K}^{+}$-ATPase in rat brain. Alcohol, alcohol-kolanut and alcohol-caffeine, on the other hand, produced a remarkable decrease in the activity of $\mathrm{Na}^{+}-\mathrm{K}^{+}$-ATPase. These effects could be attributed to the perturbation of the ionic equilibrium of the nerve receptors. The results showed that $\mathrm{Na}^{+}$$\mathrm{K}^{+}$-ATPase, which maintains ionic homeostasis in the brain was inhibited by alcohol-kola nut interaction. The major effect was the pertubation of the ionic equilibrium of the nerve receptors during which the $\mathrm{Na}^{+}-\mathrm{K}^{+}$-ATPase was essentially by-passed with the results that $\mathrm{K}^{+}$ ion very rapidly left the brain nerve cells, resulting in a decrease in ATP production, and ionic transport, hence reduced activity of $\mathrm{Na}^{+-}$ $-\mathrm{K}^{+}$-ATPase. Alcohol-kolanut interaction increased the passive $\mathrm{Na}^{+}$conductance of nerves by blocking the action potential. This prevented normal conformational changes in membrane proteins from occurring when the nerve was depolarized, and inhibited the stimulation of the nerve axons(Kalant and Rangaral, 1981; Szekeres, 1996; Gloor, 1997).

The $\mathrm{Na}^{+}-\mathrm{k}^{+}$-ATPase or sodium pump, is the membrane-bound enzyme that maintains the $\mathrm{Na}^{+}$and $\mathrm{k}^{+}$gradients across the plasma membrane of animal cells. Because of its importance in many basic and specialized cellular function, this enzyme must be able to adapt to changing cellular and physiological stimuli. The basic function of the $\mathrm{Na}^{+}-\mathrm{k}^{+}-$ ATPase or sodium pump is to maintain the high
$\mathrm{Na}^{+}$and $\mathrm{K}^{+}$gradient across the plasma membrane of animal cells (Hernandez, 1992).

In particular, the sodium pump is the major determinant of cytoplasmic $\mathrm{Na}^{+}$, thus, playing an important role in regulating cell volume, cytoplasmic $\mathrm{pH}$ and $\mathrm{Ca}^{2+}$ levels through the $\mathrm{Na}^{+} / \mathrm{H}^{+}$and $\mathrm{Na}^{+} / \mathrm{Ca}^{+}$exchangers, respectively, and in driving a variety of secondary transport processes such as $\mathrm{Na}^{+}$dependent glucose and amino acid transport (Blaustein, 1977; Clausen, 1996; Doucet, 1997; Bonvalet, 1998; Beltowski et al, 1998).

One of the primary needs for sodium pump adoption comes from changes in dietary $\mathrm{Na}^{+}$and $\mathrm{K}^{+}$. The mediators of natriuresis and diuresis, namely: hormones that control the volume and ionic composition of blood and urine, often act directly on the sodium pump of the kidney and intestine. The function of the pump in absorption or reabsorption of $\mathrm{Na}^{+}$and $\mathrm{K}^{+}$, and secondarily, other solutes, requires tight regulation of the enzyme to maintain normal levels of $\mathrm{Na}^{+}$and $\mathrm{K}^{+}$during altered salt intake (Holtug et al, 1996; Doucet, 1997, Dunham and Blostein, 1997). In addition, because water and $\mathrm{Na}^{+}$transport across epithelia are invariably linked, the work of the sodium pump is also critical to water absorption in the intestine and reabsorption in the kidney. Impairment of the sodium pump in kidney and small intestine can be associated with the pathophysiology of hypertension (Hussian et al, 1998) and chronic diarrhea (Fondacaro, 1986; Bertorello and Aperia, 1990), respectively.

In excitable tissues such as neurons, skeletal muscle cells, and pacemaker fibers of the heart, the sodium pump must restablish the electrical potential across the plasma membrane 
following excitation-induced depolarization (Szekers, 1996; Clausen, 1996; Gloor, 1997). In skeletal muscle, regulation of sodium pump activity has widespread physiological implications, continuous stimulation of muscle fibre during exercise leads to dissipation of the cation gradient necessary for muscle contraction, and to offset excessive release of $\mathrm{K}^{+}$from the muscle cells, rapid activation of $\mathrm{Na}^{+}-\mathrm{K}^{+}$ATPase activity under these conditions is an essential means of delaying the onset of muscular fatigue and reducing potentially toxic levels of plasma $\mathrm{K}^{+}$. $\mathrm{Na}^{+}-\mathrm{K}^{+}$-ATPase regulation on cardiac muscle is particularly critical to the myocardium where the enzyme controls the steady-state cytoplasmic $\mathrm{Na}^{+}$concentration, which then determines $\mathrm{Ca}^{2+}$ concentration via the $\mathrm{Na}^{+} / \mathrm{Ca}^{2+}$ exchanger. $\mathrm{Ca}^{2+}$, in turn, is pumped into the sarcoplasmic reticulum (SR) by the sarco (endo) plasmatic reticulum calcium (SERCA) pumps (Chapman and Greedwood, 1988). Regulation of the sodium pump in these tissues is therefore paramount for determining the set point for cardiac muscle contraction and the steady-state contraction of vascular smooth muscle. Physiological regulators that act in a manner analogue to that of cardiac glycoside inhibitors of the $\mathrm{Na}^{+}-\mathrm{k}^{+}$-ATPase are likely to be critical for normal heart contraction. Thus, the mechanism of increasing the cell $\mathrm{Na}^{+}$may be the basis of digitalis therapy for cardiac insufficiency (Thomas et al, 1990; Meister and Aperia, 1993; Clausen and Nielson, 1994).

Alcohol-kolanut interaction had led to compensatory changes in neuronal membrane structures involved in impulse conduction and transmission, and these changes become manifest as increased tolerance and withdrawal hyperexcitability. With increasing withdrawal hyperexcitability, the sodium pump $\left(\mathrm{Na}^{+}-\mathrm{K}^{+}-\right.$ ATPase), which is involved in ion and neurotransmitter transport, increases its activity (Clausen, 1996).

Conclusively, the results showed that though Kolanut modulated the depressant effects of alcohol, it did not ameliorate the damage by alcohol to neuronal cells. The study may suggest that alcohol and kolanut interactions would result in a decrease in ATP production, ionic transport and activity of $\mathrm{Na}^{+}-$ $\mathrm{K}^{+}$-ATPase, which may inhibit the action potential, leading to loss of neuronal activities.

\section{References}

Abulude, F. O. (2004). Composition and properties of kola nitida and kola accuminata flour in Nigeria. Global Journal of Pure and applied Science, 10 (1), 11-16.
Adeyeye, E. I. and Ayejuyo, O. O. (1994). Chemical composition of kola acuminate and Garcina kola seeds grown in Nigeria. International Journal of food science and Nutrition, 45, 223-230.

Beltowski, J., Gorry, D., and Marciniak, A. (1998). The mechanism of $\mathrm{Na}^{+}-\mathrm{k}^{+}$-ATPase inhibition by atrial natriuretic factor in rat renal medulla. J. Physiol. Pharmacol,. 49:271-283.

Bertorello, A, and Aperia, A. (1990). Short-term of $\mathrm{Na}^{+}-\mathrm{k}^{+}$-ATPase activity by dopamine. American Journal of Hypertension, 3:515545.

Blaustein, M. P. (1977). Sodium ions, calcium ions and blood pressure regulation, and hypertension: a reassessment and a hypothesis. American Journal of Physiology Cell Physiology, 232:C165 C173.

Bonvalet, J. P. (1998). Regulation of sodium transport by stercid hormones. Kidney Int Suppl., 65:549-556.

Chapman, G. E. and Greenwood, C. E. (1988). Stimulation of brain $\mathrm{Na}+\mathrm{k} \underline{+} \mathrm{ATPase}$ by norepinephrine but not taurine. Neurochem. Res. 13:77-82.

Clausen, T. (1996). The Na $\underline{k} \pm$ ATPase in skeletal muscle: quantification, regulation and function significance. Acta Physiol scand. 156:227-235.

Clausen, T and Nielson, O. B. (1994). The $\mathrm{Na}+\mathrm{k}+\mathrm{ATPase}$ and muscle contractivity. Acta Physiol Scand 152:365-573.

Danbolt, N.C. (2001). Glutamate uptake. Journal of Neurobiology, 65(1), 100-105.

Dorhman, D. P., West, J. R. and Pantazis, N. J. (1997). Ethanol reduces expression of the nerve growth factor receptors, but not nerve growth factor protein levels in the neonatal rat cerebellum. Alcohol Clinical Experimental Research, 21(5), 882-893.

Doucet, A. (1988). Function and control of $\mathrm{Na}^{+}-$ $\mathrm{k}^{+}$-ATPase in single nephron segments of the mammalian kidney. Kidney International. 34:749-760.

El-mas, M. M., Tao, S., Carrol, R. G. and Abdel-Rahman, A. A. (1994). Role of alcohol on central nervous system, Alcohol, 11, 307-314.

Eteng, M. U Eyong, E. U, Akpanyong, E. O, Agiang, M. A and Aremu, C. Y (1997). Recent avances in caffeine and theobromine toxicities: A review. Plant Food for Human Nutrition, 51, 231-243.

Fadda, F. and Rossetti, Z.L. (1998). Chronic ethanol consumption: From Neuroadaption to neurodegeneration. Journal of Neurobiology, 56(4), 385-431. 
Fiske, C. H and Subbarow, Y. (1925). Colorimetric determination of Phosphorus. Journal of Biological Chemistry, 6, 175180.

Fondacero, J. D. (1986). Intestinal ion transport, and diarrhea disease. American Journal of Physiological Gastrointest Liver Physiol. 250:G1-G8.

Gloor, S. M. (1997). Relevance of $\mathrm{Na} \pm \mathrm{k} \pm$ ATPase to local extracellular potassium homeostasis and modulation of synaptic transmission. FEBS letter 412:14.

Hernandez, R. J. (1992). $\quad \mathrm{Na}^{+}-\mathrm{k}^{+}$-ATPase regulation by neurotransmitters. Neurochem Int 20:1-10.

Holtug, K, Hansen, M. B. and Skadhauge, E. (1996). Experimental studies of intestinal ion and water transport. Scand J. Gastroenterol Suppl., 216:95-110.

Kalant, H. and Rangaral, N. (1981). Interaction of catecholamines and ethanol on the kinetics of rat brain $\mathrm{Na}^{+}-\mathrm{k}^{+}$-ATPase. Eur. J. Pharmacol., 70:157-166.

Koobs, G. F., Roberts, A. J., Schulteis, G. Parsons, L. H, Heyser, C. J, Hyytia, P, Merlopich, E. and Weiss, F. (1998). Neurocircuitry targets of ethanol reward and dependence. Alcohol, Clinical Experimental Research, 22(1), 3-9.

Lieber, C. S. (1999). Interaction of ethanol with drugs, hepatic agents, carcinogens and vitamins. Alcohol, Alcoholism, 25,157176.
Lieber, C. S. (2000). Pathway of ethanol metabolism and related pathology. In T.N. Palmer (ed). Alcoholism: A molecular perspective (pp.1-25). New York: Plenum Press.

Meister, B and Aperia, A (1993). Molecular mechanisms involved in catecholamines regulation of sodium transport. Semin Nephrol. 13:41-49.

Obochi, G. O. (2006). Effect of alcohol-kola nut interaction on biochemical indices of neuronal function and gene expression in wistar albino rats. A Ph.D thesis submitted to the Graduate School, University of Calabar, Nigeria.

Sigstrom, L. Walderstrom, J (1980). Characteristic of active Sodium and Potassium transport in erythrocyte of healthy infants and children. Acta Journal of Paediatry, 29,273-280.

Sigstrom, L. Walderstrom, J. and Karbery, P. (1981). A modified method for determination of $\mathrm{Na}^{+}-\mathrm{k}^{+}$-ATPase Journal of Clinical Chemistry, Acta, 27,345-352.

Szekeres, L. (1996). On the mechanism and possible therapentic application of delayed cardiac adaptation to stress. Can $\mathbf{J}$ cardiol 12:177-185.

Thomas, R, Gray, P. and Andrews, J. (1990). Digitalis: Its mode of action, receptor and structure activity relationship. Adv. Drug Res. 19:311-362.

Received: $9 / 8 / 2007$

Accepted: 5/10/2007 